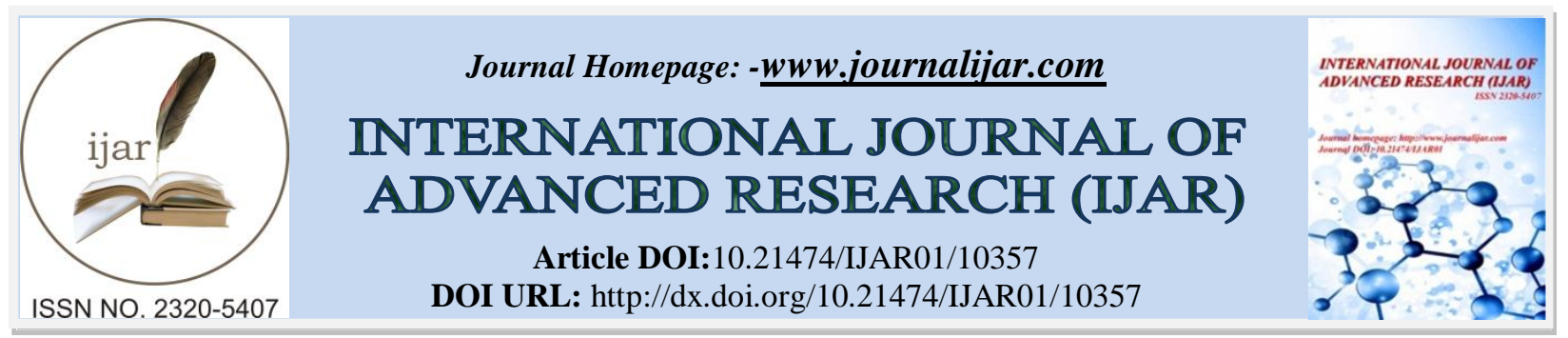

RESEARCH ARTICLE

\title{
MULTIVALVULAR INVOLVEMENT IN SCHEIE SYNDROME
}

\author{
B. Madhava Rao, L. Srinivasa Rao, S. Satya Kumar K, M. Rajasekhar Reddy, D. Harshavardan and B. Gowtham \\ Department of General Medicine, Maharaja Institute of Medical Sciences, Nellimarla 535217, Andhra Pradesh, South \\ India.
}

\section{Manuscript Info}

\section{Manuscript History}

Received: 30 November 2019

Final Accepted: 31 December 2019

Published: January 2020

Key words:-

Mucopolysaccharidoses - Scheie Syndrome,

Multivalvuar Involvement

\section{Abstract}

Mucopolysaccharidoses - Scheie syndrome (MPS 1-S) reappraisal with multi- valvular involvement diagnosed by clinical and radiological findings, and confirmed by biochemical features is reported. Two dimensional and doppler echocardiography were of enormous help in not only finding the valvular lesions but also their severity.

\section{Introduction:-}

The mucopolysaccharidoses constitute a group of heritable disorders characterised by abnormal accumulation of mucopolysaccharide material in various tissues. They are diagnosed by a combination of clinical, radiological and biochemical features. The mucopolysaccharidoses (MPS) are genetically classified into seven types by McKusick V.A. ${ }^{1}$ A common feature of several of these disorders is cardiac involvement. We report a family of Scheie syndrome (MPS I-S) with multivalvular involvement. To the best of our knowledge this is being reported for the first time in India.

\section{Material and Methods:-}

Two sisters RP and RK were born fullterm and normally to distantly related Parents. RP and RK had slightly delayed milestones of.development. From the age of 4 years parents noticed coarse facies (Fig. 1), joint stiffness, widening of wrists, clawing of hands and progressive kyphoscoliosis. She was suffering from progressive dyspnoea on exertion for the past six months and suffered one episode of effort syncope at the age of 9 years. Physical examination revealed head circumference of $54 \mathrm{~cm}$, normal intelligence, peripheral clouding of cornea with clear centre, thick lips, enlarged tongue and restricted mobility of small joints of hands and feet, wrists, elbows, knees with kyphoscoliosis. Firm liver was palpable $3 \mathrm{~cm}$ below the right coastal margin. Cardiovascular system revealed pulse 80 per mt, regular, low volume, no brachiofemoral delay. B.P.100/90 rnm, Hg. J.V.P. $5 \mathrm{~cm}$ from sternal angle with prominent 'a' and 'v' waves. Apex was not localised. First sound was muffled second sound was normally split with

soft A2 and loud P2. There was no opening snap. A grade 3/6 ejection systolic murmur was heard over the aortic area with conduction to the carotids and grade 2/6 pansystolic murmur at the apex with conduction to the left axilla. A rough, rumbling middiastolic murmur with presystolic accentuation was also heard at the apex. Respiratory and neurologic systems were normal.

RK had normal milestones of development and was asymptomatic except for milder degree of stiffness of various joints. She had relatively less coarse facies (Fig. 1), height of112 cms, head circumference of $51 \mathrm{cms}$, normal intelligence, peripheral 


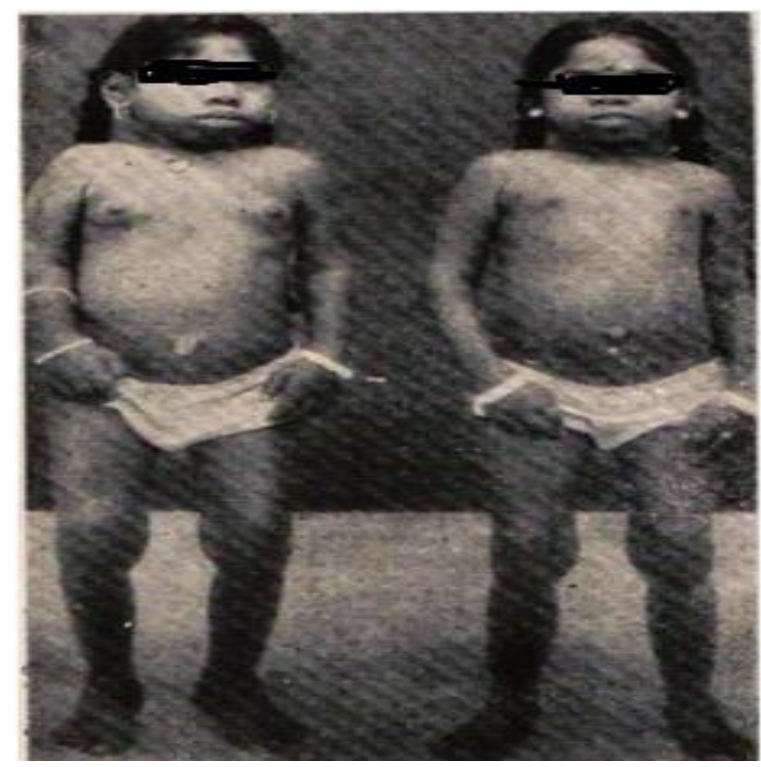

Fig1:- Photograph of RP 16/F and RK 14/F.

Clouding of cornea with clear centre, mild restriction of motion of small joints of hands and feet, elbows, wrists, knees and ankles. Her spine was normal. Cardiovascular system was clinically normal except for grade $2 / 6$ ejection systolic murmur over the second left intercoastal space. Hepatomegaly of $3 \mathrm{~cm}$ was present. Respiratory and neurologic systems were normal.

\section{Investigations:}

Routine blood and urinalysis were essentially normal. E.C.G. of C.G. showed sinus rhythm, heart rate of 75 per mt, left atrial enlargement, left axis deviation, left ventricular hypertrophy, normal ST-T and no conduction abnormalities. Skiagram of chest showed cardiothoracic ratio of 60\%, L.V. enlargement, left atrial enlargement and mild pulmonary venous hypertension. $\mathrm{X}$ rays of hands showed (Fig. 2) classical broad metacarpals2,3 with widening of shafts, fingers were held in a 'claw' position with cystic changes in the phalanges, the phalanges were short and expanded resembling bullets, the inferior radioulnar joint was ' $v$ ' shaped (arrow marked in Fig.3) with epiphyseal irregularity. Spine revealed dorsal kyphoscoliosis. Fluroscopy of heart showed densely calcified mitral valve and mildly calcified aortic valve. E.C.G. of RP was normal except for short P-R interval $(80 \mathrm{msec})$. Skiagrams of skull, pelvis, spine, chest were normal. Radiological findings of wrist joints and hands were similar to that RP (Fig. 3). Fluroscopy of heart showed no calcification in cardiac structures. Findings of two-dimensional and doppler echocardiography of both patients are shown in Table I

\section{Scheie Syndrome With Multivalvular Involvement:}

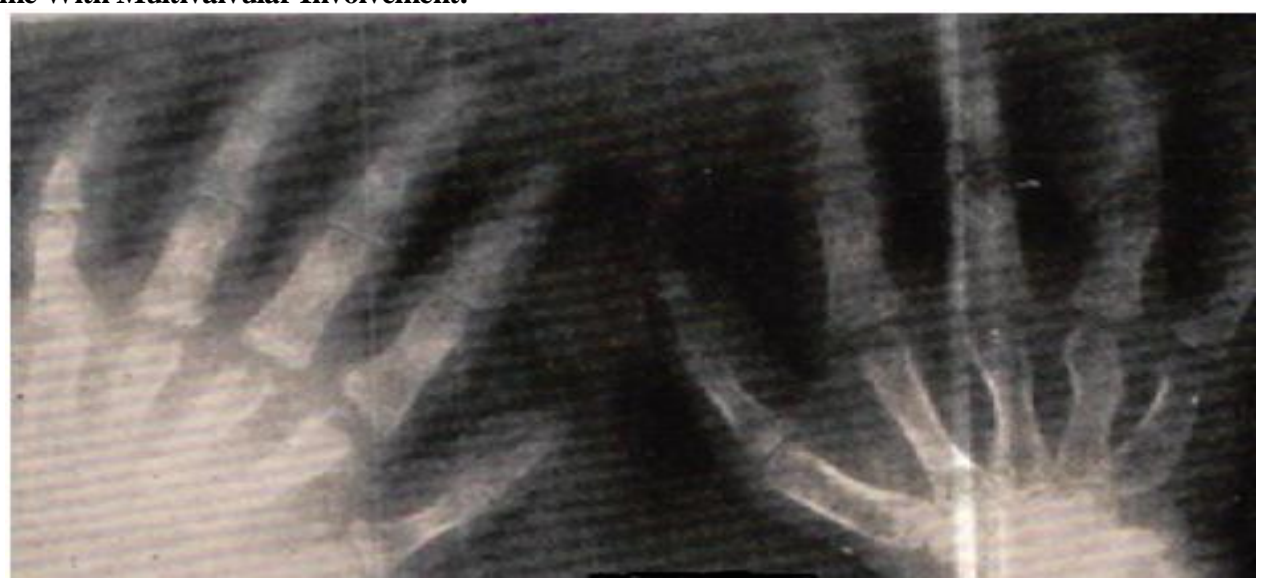

Fig. 2: $\mathrm{X}$ - ray of both wrists and hands of RP16/F. 
Table1:- 2D echocardiogram and pulsed doppler findings.

\begin{tabular}{|c|c|c|}
\hline Case / age / sex & RP 16F & RK $14 \mathrm{~F}$ \\
\hline Mitral vale & $\begin{array}{l}\text { Thickened, calcified and domed. Diastolic } \\
\text { spectral broadening and increased flow } \\
\text { velocity in the left ventricle distal to leaflets. } \\
\text { Calculated gradient } 16 \mathrm{~mm} \mathrm{Hg} \text {. Abnormal systo- } \\
\text { lic flow in left atrium proximal to leaflets. }\end{array}$ & $\begin{array}{l}\text { Thickened and domed. Diastolic spectral } \\
\text { broadening and increased flow velocity in } \\
\text { left ventricle distal to leaflets. Calculated } \\
\text { gradient } 12 \mathrm{~mm} \mathrm{Hg} \text {. Abnormal systolic } \\
\text { flow in left atrium proximal to leaflets. }\end{array}$ \\
\hline Aortic valve & $\begin{array}{l}\text { Calcified and domed. Increased peak } \\
\text { systolic flow velocity in ascending } \\
\text { aorta distal to the cusps. No AR. } \\
\text { Tricuspid valve Normal movements. } \\
\text { Abnormal systolic flow in right atrium } \\
\text { proximal to leaflets }\end{array}$ & $\begin{array}{l}\text { Thickened and domed. Increased peak } \\
\text { systolic flow velocity in ascending aorta distal } \\
\text { to the cusps. No AR Normal movements. } \\
\text { Abnormal systolic flow in right atrium } \\
\text { proximal to leaflets. }\end{array}$ \\
\hline Pulmonary valve & Normal & Normal \\
\hline Final impression & $\begin{array}{l}\text { Severe mitral stenosis, severe aortic } \\
\text { stenosis, mild mitral regurgitation, mild } \\
\text { tricuspid regurgitation. }\end{array}$ & $\begin{array}{l}\text { Moderate mitral stenosis, moderate aortic } \\
\text { stenosis, mild mitral regurgitation, mild } \\
\text { tricuspid regurgitation. }\end{array}$ \\
\hline
\end{tabular}

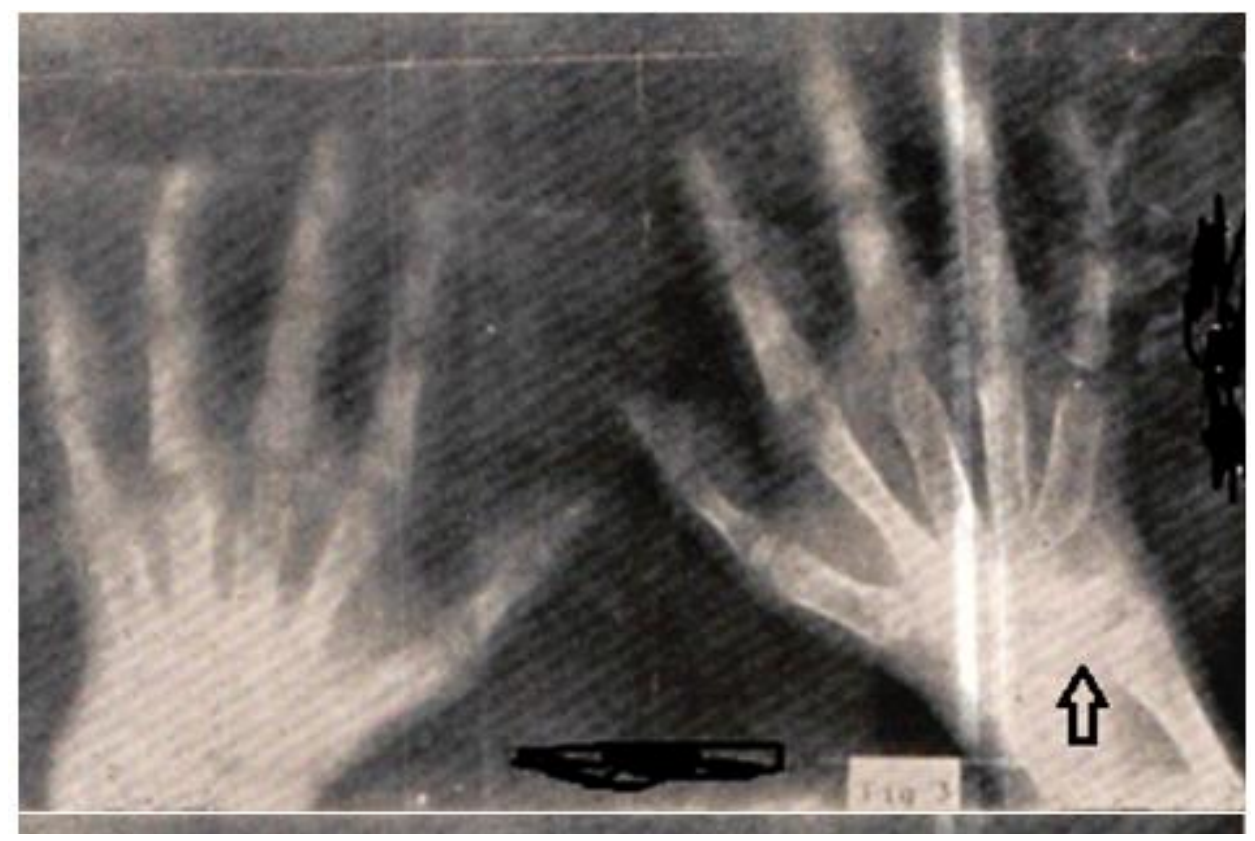

Fig. 3: X-ray of both wrists and hands of RK 14/F.

\section{Biochemical studies:}

Urine analysis. 24 hours urine samples of both patients were analysed quantitatively and qualitatively for the different types of glycosaminoglycons and the total uronic acid was estimated following the method of Bitter and Muir. 4 The results are shown in Table II.

Enzyme studies in leukocytes. $\alpha$-L-iduronidase was assayed in the leukocytes of both patients and their parents following the method of Rome et $\mathrm{al}^{6}$ using 4-methylumbelliferyl $\alpha$-L-iduronide as the substrate. The results are shown in Table III.

\section{Discussion:-}

Analysing the clinical, radiological and biochemical findings (urinary excretion of Heparan and Dermatan sulfates, absent leukocytic $\alpha$-L-iduronidase activity) the above family of two cases comes under type I mucopolysaccharidoses, the Hurlersyndrome (MPS 1-H), the Scheie syndrome (MPS 1-S) and the Hurler-Schete compound (MPS 1-HIS). The 
first one is wholly excluded on the grounds that death ensues usually before the age of ten years, the associated abnormalities being severe and the urinary

Excretion ratio of Dermatan and Heparan sulfate being less than $3: 1$. The Hurler-Scheie compound is also ruled out because there is no mental retardation in our cases. Therefore our cases are categorised into Scheie syndrome. A common feature of all mucopolysaccharidoses is cardiac involvement. In Scheie syndrome the typical cardiac lesion is

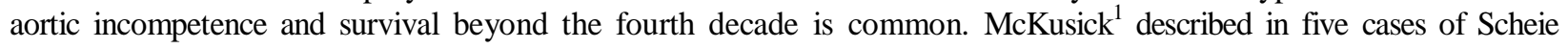
syndrome two basal systolic murmurs,

Table II:- Results of urinalysis.

\begin{tabular}{|l|l|l|l|l|}
\hline Case & Total AMPS• in mg/24 hours & \%, Fractions & \multicolumn{3}{|c|}{ DeS A and c } \\
\cline { 3 - 5 } & & He S & 37.60 & 42.67 \\
\hline RP 16/F & 29.4 & 22.13 & 42.8 & 37.7 \\
\hline RK 14/F & 12 & 19.5 & 83 & 6 \\
\hline $\begin{array}{l}\text { Normal } \\
\text { values }\end{array}$ & 2.5 & 11 & & \\
\hline
\end{tabular}

*Expressed as milligrams of uronic acid per 24 hours. HeS — Heparan sulfate: Ch A \& C — Chondroitin A and C sulfates; DeSDermatan sulfate.

Table III:- Results of a-L-iduronidase assay in leukocytes.

\begin{tabular}{|l|l|l|}
\hline Case & Age/Sex & Leukocyte a-L-iduro nidase $\mathrm{pm} / \mathrm{hr} / \mathrm{mg}$ protein \\
\hline RP & $16 \mathrm{~F}$ & N.D. \\
\hline RK & $14 \mathrm{~F}$ & N.D. \\
\hline Father & $48 \mathrm{M}$ & 1004 \\
\hline Mother & $37 \mathrm{~F}$ & 1136 \\
\hline Normal & & $1100 \mathrm{f} 200$ \\
\hline
\end{tabular}

\section{N.D.=Not detectable:}

two apical systolic murmurs and two diastolic murmurs. Wilson.et.al reported cases of MPS I-S with severe aortic stenosis in two brothers. In the cases under discussion we found evidence of aortic stenosis, mitral stenosis, mitral incompetence and tricuspid incompetence based on our clinical, radiological, two-dimensional and doppler echocardiographic findings. Although Wilson et al reported two cases of severe valvular aortic stenosis in Scheiesyndrome but definite evidence of mitral valve involvement as described in our cases has not been reported in this or any other report in Scheie syndrome to the best of our knowledge. Schieken et al evaluated noninvasively using M-mode echo- cardiogram, nine cases of mucopolysaccharidoses to find out the involvement of various cardiac structures and reported mitral valve calcification in MPS I-HIS, mitral and aortic valve involvement in MPS VI-A (Maroteaux-Lamy syndrome, classic form) but their only patient with scheie syndrome (MPS I-S) did not reveal any cardiac lesion.

In our cases detailed noninvasive assessment by various methods including two-dimensional and doppler echocardiography were performed and exact diagnosis and severity of various lesions were established. Thus detailed noninvasive assessment by two-dimensional and doppler echocardiographic examination in patients with various mucopolysaccharidoses would enable to detect many more cases with multivalvular involvement and help in decision making for corrective surgery in some of the suitable cases.

\section{Acknowledgement:-}

We are thankful to deparment of biochemistry in evaluation and confirming the diagnosis with reagent 4methylumbelliferyl iduronidase., also to parents for giving consent for blood analysis,taking X-rays and photographs.

\section{References:-}

1. McKusick VA.Themucopolysaccharido- ses, in heritable disorders of connective tissue. 4th ed., St. Louis : C.V. Mosby, 1972: p 521

2. Murray RO, Jacobson HG eds. Radiology of the skeletal disorders. 2nd ed., Edinburgh \& New York : Churchill Livingstone, 1977

3. Shanks SC, Peter Kerlay eds. A Text Book of X-ray diagnosis. 4th ed. London : H.K. Lewis Co. Ltd. 1971 : p 589 
4. Bitter T, Muir HM. A modified uronic acid carbazole reaction. Anal Biochem 1962; 4:330-334

5. Di Ferrante N, Rich C. The determination of acid mucopolysaccharides. J Lab Clin Med 1956; 48 : 491-494

6. Rome LH, Weissmann B, Neufeld EF. Direct demonstration of binding of lysosomal enzyme $\alpha$-L-idurolidase to receptors on cultured fibroblasts. Proc Nall Acad Sci USA 1979; 76 : 2331-2334

7. Rudolph AM, Hoffman JLE eds. Paediatrics 17th ed. Connecticut : Appleton-Century- Crofts, Norwalk, 1982 : p 337. 